\title{
OPEM
}

www.opem.org

Oriental Pharmacy and Experimental Medicine 2009 9(2), 115-127

DOI 10.3742/OPEM.2009.9.2.115

\section{Samsoeum inhibits systemic anaphylaxis and release of histamine, cytokine in vivo and in vitro}

\author{
Su-Jin Kim ${ }^{1,4}$, Na-Hyung Kim ${ }^{1}$, Phil-Dong Moon ${ }^{1}$, Noh-Yil Myung ${ }^{1}$, Min-chol Kim ${ }^{4}$, Ki-Taek Lee ${ }^{4}$, \\ Hyung-mook $\mathrm{Jo}^{4}$, Na-Hyun Kim ${ }^{4}$, Hong-Kun Rim ${ }^{1}$, Min-Jun Seo ${ }^{4}$, Jin-Man Kim ${ }^{3}$, Seung-Eun Lee ${ }^{3}$, \\ Nyeon-Hyung $\mathrm{An}^{4}$, Kang-Min Lee ${ }^{2}$, Si-Hyung Lee ${ }^{3}$, Yun-Jum Park ${ }^{5}$, Hyun-Ja Jeong ${ }^{6}$, Jae-Young \\ $\mathrm{Um}^{1}$, Hyung-Min Kim ${ }^{1}$ and Seung-Heon Hong ${ }^{4, *}$
}

${ }^{1}$ College of Oriental Medicine, Institute of Oriental Medicine, Kyung Hee University, 1 Hoegi-Dong, Dongdaemun-Gu, Seoul, 130-701, Republic of Korea; ${ }^{2}$ Division of Biological Sciences, College of Natural Science, Chonbuk National University, Jeonju, Jeonbuk 561-756, Republic of Korea; ${ }^{3}$ College of Oriental Medicine, Wonkwang University, Iksan, Chonbuk, 570-749, Republic of Korea; ${ }^{4}$ Wonkwang-Oriental Medicines Research Institute and College of Pharmacy, Wonkwang University, Iksan Jeonbuk 570-749, Republic of Korea; ${ }^{5}$ Division of Horticulture and Pet Animal-Plant Science, Wonkwang University, Iksan, Republic of Korea, ${ }^{6}$ Biochip Research Center, Hoseo University, Asan, Chungnam, Republic of Korea

Received for publication May 14, 2009; accepted June 10, 2009

\begin{abstract}
SUMMARY
Samsoeum (SSE) is used in traditional oriental medicine for various medicinal purposes. However, the exact mechanism that accounts for the anti-allergy and anti-inflammatory effects of the SSE is still not fully understood. The aim of the present study is to elucidate whether and how SSE modulates the allergic reactions in vivo, and inflammatory reaction in vitro. In this study, we showed that SSE significantly decreased compound 48/80-induced systemic anaphylaxis, earswelling response, histamine release from preparation of rat peritoneal mast cells and antidinitropheny IgE-induced passive cutaneous reaction. Also, SSE inhibited the expression of inflammatory cytokine and cyclooxygenase-2 in PMA plus A23187-stimulated human mast cells (HMC-1). In addition, we showed that anti-inflammatory mechanism of SSE is through suppression of nuclear factor- $\kappa \mathrm{B}$ activation and I $\mathrm{KB}-\alpha$ phosphorylation/degradation in HMC-1. These results provided new insight into the pharmacological actions of SSE as a potential molecule for therapy of inflammatory allergic diseases.
\end{abstract}

Key words: Samsoeum; Allergic reactions; Inflammation; Cyclooxygenase-2; Nuclear factor-кB

\section{INTRODUCTION}

Mast cells are widely distributed throughout the body in both connective tissue and mucosal

\footnotetext{
${ }^{*}$ Correspondence: Seung-Heon Hong, College of Pharmacy, Wonkwang University, Iksan Jeonbuk, 570749, Republic of Korea. Tel: +82638506805; Fax: +82638433421; E-mail: jooklim@wonkwang.ac.kr
}

surfaces (Metcalfe et al., 1997). The role of mast cells as effecter cells of immunoglobulin (Ig) E-dependent immediate-type hypersensitivity reactions and anaphylaxis is well understood (Hamelmann et al., 1999; Galli, 2000). Activation of mast cells is elicited through the cross-linking of allergen-specific IgE bound to the high-affinity receptor for IgE, FceRI, on the cell membrane, which results in the 
degranulation of mast cells and the release of mediators including histamine, proteases, leukotrienes, prostaglandin (PG)s, and different cytokines such as tumor necrosis factor (TNF)- $\alpha$, interleukin (IL)-6, and IL-8 (Gordon et al., 1990; Kawata et al., 1995; Artuc et al., 1999). Mast cells are also involved in the development of late-phase reactions and influence other chronic inflammatory responses through the generation and secretion of various cytokines (KrugerKrasagakes and Czarnetzki, 1995). Inflammatory cytokine such as TNF- $\alpha$, IL-1, IL-6, and IL-8 induce inflammation and recruit other immune cells including neutrophils and T lymphocytes (Medzhitov and Janeway, 1997). Although these cytokines are beneficial to the host defense, they can also trigger pathological conditions when expressed in excess (Beutler, 1995). Cyclooxygenase (COX)-2 is an inducible enzyme found at low concentration in healthy tissues, but it is up regulated in response to tissue damage during inflammation. There was reported that COX-2, one of the major mediators of the inflammatory reaction, is also strongly induced in activated monocytes/macrophages (Meade et al., 1993).

Nuclear factor (NF)- $\mathrm{kB}$ is a key transcription factor required for the expression of many inflammatory involved genes including COX-2 and inflammatory cytokines (Jung et al., 2003). In an inactive state, $\mathrm{NF}-\mathrm{\kappa B}$ is normally sequestered in the cytoplasm of cells where it is bound by a family of inhibitory proteins known as IкB- $\alpha$ (Barnes and Karin, 1997). A variety of stimuli modulate signal transduction pathways to activate IкB kinases. Stimulation of the activity of these kinases results in phosphorylation, ubiquitination, and degradation of IкB- $\alpha$, leading to the nuclear translocation of NF-кB (Schaecher $e t$ al., 2004).

Samsoeum (SSE) is used in traditional oriental medicine for various medicinal purposes. However, the exact mechanism that accounts for the antiallergy and anti-inflammatory effects of the SSE is still not fully understood. The aim of the present study was to elucidate whether and how SSE modulates the allergic reactions in vivo, and mast cell mediated-inflammatory reaction in vitro. Therefore, we investigate the mechanisms underlying the pharmacological effects of SSE on both compound 48/80-induced and anti-dinitropheny (DNP) IgEinduced allergic reactions in vivo. Also, to find a possible explanation for the anti-inflammatory mechanisms of SSE, we evaluate effects of SSE on phorbol 12-myristate 13-acetate (PMA) plus calcium ionophore A23187-induced production and expression of cytokine, COX-2 expression, and NF- $\mathrm{kB}$ activation.

\section{MATERIALS AND METHODS}

\section{Reagents}

Fetal bovine serum (FBS), $\alpha$-minimal essential medium and Iscove's Modified Dulbecco's Medium (IMDM) were purchased from Gibco BRL (Grand Island, NY, USA). Compound 48/80, anti-DNP IgE, DNP-human serum albumin (HSA), 2,2-azinobis (3-ethylBenzthiazoline-6-sulfonic acid), PMA, metrizamide, A23187, 3-(4,5-dimethylthiazol-2-yl)diphenyl-tetrazoliumbromide (MTT) and other reagents were obtained from Sigma (St. Louis, MO, USA). Anti-human TNF- $\alpha$ antibody (Ab), biotinylated anti-human $\mathrm{TNF}-\alpha \quad \mathrm{Ab}$, and recombinant human (rh) TNF- $\alpha$ were purchased from R\&D Systems (Minneapolis, MN, USA). Anti-human IL-6 and IL-8 Ab, biotinylated antihuman IL- 6 and IL- 8 Ab, and rh IL-6 and IL- 8 were purchased from PharMingen (Sandiego, CA, USA). Abs for anti-human NF-kB, IkB- $\alpha, p$ IкB- $\alpha$, and actin were purchased from Santa Cruz Biotech. (Santa Cruz, CA, USA).

\section{Preparation of SSE}

SSE which is a mixture of 12 traditional drugs as shown in Table 1 was obtained from the College of Pharmacy, Wonkwang University (Iksan, South Korea). Amounts of the 12 traditional drugs studied in this work were shown in Table 1. Extract of SSE was prepared by decocting the dried description of herbs with boiling distilled water. The extraction decocted for approximately 
Table 1. The ratio of the component in SSE

\begin{tabular}{|c|c|}
\hline Components & Ratio \\
\hline 1. Ginseng Radix (Panax ginseng C.A. $\mathrm{M}_{\mathrm{EYER}}$ ) & 4 \\
\hline 2. Perillae Folium (Perilla frutescens (L.) $B_{\mathrm{RITT}}$ var. acuta ( $\mathrm{T}_{\mathrm{HUNB}}$.) $\left.\mathrm{K}_{\mathrm{UDO}}\right)$ & 4 \\
\hline 3. Peucedani Radix (Peucedanum decursivum $\left(\mathrm{M}_{\mathrm{IQ}}\right.$.) $\mathrm{M}_{\mathrm{AXIM}}$ ) & 4 \\
\hline 4. Pinelliae Tuber (Pinellia ternata $\left(\mathrm{T}_{\mathrm{HUNB}}\right.$. $) \mathrm{B}_{\mathrm{REIT}}$. $)$ & 4 \\
\hline 5. Puerariae Radix (Pueraria thunbergiana $\left(\mathrm{S}_{\mathbb{I E B}}\right.$ et $\mathrm{Z}_{\mathrm{UCC}}$ ) $\mathrm{B}_{\mathrm{ENTH}}$.) & 4 \\
\hline 6. Hoelen (Poria $\operatorname{cocos} \mathrm{W}_{\text {off }}$ ) & 4 \\
\hline 7. Aurantii nobilis Pericarpium (Citrus unshiu $\mathrm{M}_{\mathrm{ARCOR}}$ ) & 3 \\
\hline 8. Platycodi Radix (Platycodon grandiflorum (JACQ.) A. DC.) & 3 \\
\hline 9. Glycyrrhizae Radix (Poncirus trifoliata (L.) $\mathrm{R}_{\mathrm{AF}}$.) & 3 \\
\hline 10. Zingiberis Rhizoma (Glycyrrhiza uralensis $\mathrm{F}_{\mathrm{ISCH} .}$ ) & 3 \\
\hline 11. Zizyphi inermis Fructus (Zingiber officinale $\mathrm{R}_{\mathrm{Osc}}$.) & 3 \\
\hline 12. Ponciri Fructus (Ziziphus jujuba $M_{I L L}$. var. intermis ( $\left.\mathrm{B}_{\mathrm{UNGE}}\right) \mathrm{R}_{\mathrm{EHD}}$.) & 3 \\
\hline
\end{tabular}

$3 \mathrm{~h}$ has been filtered, lyophilized, and kept a $4{ }^{\circ} \mathrm{C}$. The yield of extraction was about $12 \%$. Dilutions were made in saline then filtered through 0.45mm syringe filter.

\section{Animals}

The original stock of ICR mice and Wistar rats were purchased from the Dae-Han Experimental Animal Center (Eumsung, South Korea), and the animals were maintained in the College of Pharmacy, Wonkwang University. The rats were housed five to ten per cage in a laminar air-flow room maintained at a temperature of $22 \pm 1^{\circ} \mathrm{C}$ and relative humidity of $55 \pm 10 \%$ throughout the study. No animal was used more than once. The research was conducted in accordance with the internationally accepted principles for laboratory animal use and care as found in the US guidelines (NIH publication \#8523 , revised in 1985).

\section{Compound 48/80-induced systemic anaphylactic reaction}

Mice were given an intraperitoneal injection of the mast cell degranulator compound 48/80 (8 mg/ $\mathrm{kg}$ ). SSE was dissolved in saline and administered orally $1 \mathrm{~h}$ before the injection of compound 48/80. Mortality was monitored for $23 \mathrm{~min}$ after induction of anaphylactic reaction.

\section{Ear-swelling response}

Compound 48/80 was freshly dissolved in saline and injected intradermally into the dorsal aspect of a mouse ear using a microsyringe with a 29-gauge hypodermic needle. Ear thickness was measured with a digimatic micrometer (Mitutoyo, Japan) under mild anesthesia. Ear-swelling response represented an increment in thickness above baseline control values. Ear-swelling response was determined 40 min after compound $48 / 80$ or vehicle injection. SSE was administered orally $1 \mathrm{~h}$ before the compound 48 / 80 injection $(100 \mathrm{mg} / \mathrm{site})$. The values obtained would appear to represent the effect of compound 48/80 rather than the effect of the vehicle injection (physical swelling), since the ear-swelling response evoked by physiologic saline returned to almost baseline thickness within $40 \mathrm{~min}$.

\section{Passive cutaneous reaction (PCA)}

IgE-dependent cutaneous reaction was generated by sensitizing the skin with an intradermal injection of anti-DNP IgE followed $48 \mathrm{~h}$ later with an injection of DNP-HSA into the mice tail vein. The DNP-HSA was diluted in phosphate-buffered saline (PBS). The mice were injected intradermally with $100 \mathrm{ng}$ of anti-DNP IgE into each of three dorsal skin sites. The sites were outlined with a water-insoluble red marker. Forty-eight hours 
later, each mouse received an injection of $200 \mathrm{ml}$ of the $1: 1$ mixture of $1 \mathrm{mg} / \mathrm{ml}$ DNP-HSA in PBS and $4 \%$ Evans blue via the tail vein. One hour before this injection, SSE was administered orally. The mice were sacrificed $40 \mathrm{~min}$ after the intravenous challenge. The dorsal skin of the mouse was removed for measurement of the pigment area. The amount of dye was then determined colorimetrically after extraction with $0.5 \mathrm{ml}$ of $1.0 \mathrm{~mol} / 1 \mathrm{KOH}$ and $4.5 \mathrm{ml}$ of a mixture of acetone and phosphoric acid (with the ratio of 5 :13). The absorbent intensity of the extraction was measured at $620 \mathrm{~nm}$ in a spectro- fluorometer, and the amount of dye was calculated with the Evans blue measuring-line.

\section{Preparation of rat peritoneal mast cells (RPMCs)} RPMCs were isolated as previously described (Jippo-Kanemoto et al., 1993). In brief, rats were anesthetized by ether, and injected with $20 \mathrm{ml}$ of Tyrode buffer $\mathrm{B}\left(\mathrm{NaCl}\right.$, glucose, $\mathrm{NaHCO}_{3}$, and $\mathrm{NaH}_{2} \mathrm{PO}_{4}$ ) containing $0.1 \%$ gelatin into the peritoneal cavity; the abdomen was gently massaged for about $90 \mathrm{~s}$. The peritoneal cavity was carefully opened, and the fluid containing peritoneal cells were aspirated by Pasteur pipette. Then the peritoneal cells were sedimented at $150 \times \mathrm{g}$ for 10 min at room temperature and resuspended in Tyrode buffer B. Mast cells were separated from the major components of rat peritoneal cells (i.e. macrophages and small lymphocytes) according to the method described by Yurt et al (1997). In brief, peritoneal cells suspended in $1 \mathrm{ml}$ of Tyrode buffer B were layered onto $2 \mathrm{ml}$ of $0.225 \mathrm{~g} / \mathrm{ml}$ metrizamide (density $1.120 \mathrm{~g} / \mathrm{ml}$ ) and centrifuged at room temperature for $15 \mathrm{~min}$ at $400 \times \mathrm{g}$. The cells remaining at the buffer-metrizamide interface were aspirated and discarded; the cells in the pellet were washed and resuspended in $1 \mathrm{ml}$ of Tyrode buffer $\mathrm{A}(10 \mathrm{mM}$ HEPES, $130 \mathrm{mM} \mathrm{NaCl}, 5 \mathrm{mM} \mathrm{KCl}, 1.4 \mathrm{mM} \mathrm{CaCl}_{2}$, $1 \mathrm{mM} \mathrm{MgCl} 25.6 \mathrm{mM}$ glucose and $0.1 \%$ bovine serum albumine) containing calcium. Mast cell preparation was about $95 \%$ pure as assessed by toluidine blue staining. More than $97 \%$ of the cells were viable judged by trypan blue uptake.

\section{Histamine assay}

RPMCs suspensions $\left(2 \times 10^{5}\right.$ cells $\left./ \mathrm{ml}\right)$ were preincubated for $10 \mathrm{~min}$ at $37^{\circ} \mathrm{C}$ before the addition of compound $48 / 80$ for stabilization. The cells were preincubated with the SSE for $20 \mathrm{~min}$, and then incubated for $15 \mathrm{~min}$ with compound 48/80 (6 $\mathrm{mg} / \mathrm{ml})$. The reaction was stopped by cooling the tubes in ice. The cells were separated from the released histamine by centrifugation at $400 \times \mathrm{g}$ for 5 min at $4{ }^{\circ} \mathrm{C}$. Residual histamine in the cells was released by disrupting the cells with perchloric acid and centrifugation at $400 \times \mathrm{g}$ for $5 \mathrm{~min}$ at $4{ }^{\circ} \mathrm{C}$. The histamine content was measured by the ophthalaldehyde spectrofluorometric procedure of Shore et al. (1959). The fluorescent intensity was measured at $440 \mathrm{~nm}$ (excitation at $360 \mathrm{~nm}$ ) in spectrofluorometer. The inhibition percentage of histamine release was calculated using the following equation:

$\%$ Inhibition $=(A-B) \times 100 / A$

Where A is histamine release without SSE and B is histamine release with SSE.

\section{Nuclear fast red (NFR) staining}

In order to compare the status of mast cells before or after the addition of SSE would make it clear whether SSE affects the degranulation process or not, alcian blue-NFR staining was performed. Mast cells were centrifuged with cytospin at $28 \mathrm{~g}$ for 5 min and then fixed with Carnoy's solution. Cells were stained with $1 \%$ alcian blue and NFR. They were then rinsed in distilled water and gradually dehydrated in a series of $80 \%, 90 \%, 95 \%$ and $100 \%$ alcohol. The slides were cleared in xylene and mounted with mounting medium.

\section{Culture of HMC-1 cells}

Human mast cell line, HMC-1, cells were grown in IMDM medium supplemented with $100 \mathrm{IU} / \mathrm{ml}$ 
penicillin, $100 \mathrm{mg} / \mathrm{ml}$ streptomycin, and $10 \%$ heatinactivated $\mathrm{FBS}$ at $37^{\circ} \mathrm{C}$ in $5 \% \mathrm{CO}_{2}$.

\section{MTT Assay}

To test the viability of cells, MTT colorimetric assay was performed as described previously (Kim et al., 2001). Briefly, HMC- 1 cells $\left(1 \times 10^{5}\right.$ cells $\left./ \mathrm{ml}\right)$ were incubated for $8 \mathrm{~h}$ after stimulation in the absence or presence of SSE. After addition of MTT solution, the cells were incubated at $37^{\circ} \mathrm{C}$ for $4 \mathrm{~h}$. The crystallized MTT was dissolved in dimethyl sulfoxide and measured the absorbance at $540 \mathrm{~nm}$.

\section{Assay of cytokines}

TNF- $\alpha$, IL-6, and IL-8 secretion were measured by modification of an enzyme-linked immunosorbent assay (ELISA) as described previously ( $\mathrm{Na}$ et al., 2002). 96 well plates were coated with $100 \mathrm{ml}$ aliquots of anti-human TNF-a, IL-6, and IL-8 monoclonal Abs at $1.0 \mathrm{mg} / \mathrm{ml}$ in PBS at $\mathrm{pH} 7.4$ and were incubated overnight at $4{ }^{\circ} \mathrm{C}$. After additional washes, $100 \mathrm{ml}$ of cell medium or TNF- $\alpha$, IL- 6 , and IL-8 standards were added and incubated at $37^{\circ} \mathrm{C}$ for $2 \mathrm{~h}$. After $2 \mathrm{~h}$ incubation at $37^{\circ} \mathrm{C}$, the wells were washed and then $0.2 \mathrm{mg} / \mathrm{ml}$ of biotinylated antihuman TNF- $\alpha$, IL- 6 , and IL- 8 was added and again incubated at $37^{\circ} \mathrm{C}$ for $2 \mathrm{~h}$. After washing the wells, avidin-peroxidase was added and plates were incubated for $30 \mathrm{~min}$ at $37^{\circ} \mathrm{C}$. Wells were again washed and ABTS substrate was added. Color development was measured at $405 \mathrm{~nm}$ using an automated microplate ELISA reader. A standard curve was run on each assay plate using recombinant TNF- $\alpha$, IL- 6 , and IL- 8 in serial dilutions.

\section{RNA isolation and RT-PCR}

Total RNA was isolated from HMC-1 according to the manufacturers specifications using an easyBLUE RNA extraction kit (iNtRON Biotech, Seoul, South Korea). The concentration of total RNA in the final elutes was determined by spectrophotometry. Total RNA $(2.0 \mathrm{mg})$ was heated at $65^{\circ} \mathrm{C}$ for $10 \mathrm{~min}$ and then chilled on ice. Each sample was reverse- transcribed to cDNA for $90 \mathrm{~min}$ at $37^{\circ} \mathrm{C}$ using a cDNA synthesis kit (AmershamPharmacia, NJ, USA). RT-PCR was carried out with $1 \mathrm{ml}$ of a cDNA mixture, in $20 \mathrm{ml}$ final volume with $2.5 \mathrm{mM} \mathrm{MgCl}_{2}$, $200 \mathrm{mM}$ dNTPs, $25 \mathrm{pM}$ of cytokine primers, and 2.5 $\mathrm{U}$ of Taq DNA polymerase in the reaction buffer (50 $\mathrm{mM} \mathrm{KCl}, 10 \mathrm{mM}$ Tris- $\mathrm{HCl}, \mathrm{pH}$ 9, and 0.1\% Triton $\mathrm{X}-100)$. PCR was performed with the following primers for human TNF-a (5'-CAC CAG CTG GTT ATC TCT CA-3'; 5'-CGG GAC GTG GAG CTG GCC GAG GAG-3'), IL-8 (5'-CGA TGT CAG TGC ATA AAG ACA-3'; 5'-TGA ATT CTC AGC CCT CTT CAA AAA-3'), IL-6 (5'-GAT GGA TGC TTC CAA TCT GGA T-3'; 5'-AGT TCT CCA TAG AGA ACA ACA TA -3'), COX-2 (5'-TTC AAA TGA GAT TGT GGG AAA ATT GCT-3'; 5'- AGA TCA TCT CTG CCT GAG TAT CTT- $3^{\prime}$ ), and GAPDH (5'CAA AAG GGT CAT CAT CTC TG -3'; 5'-CCT GCT TCA CCA CCT TCT TG-3') were used to verify if equal amounts of RNA were used for reverse transcription and PCR amplification from different experimental conditions. The annealing temperature was $60^{\circ} \mathrm{C}$ for TNF-a and IL-8, $50{ }^{\circ} \mathrm{C}$ for IL-6, $55^{\circ} \mathrm{C}$ for COX-2 and $62^{\circ} \mathrm{C}$ for GAPDH, respectively. Products were electrophoresed on a $1.5 \%$ agarose gel and visualized by staining with ethidium bromide.

\section{Preparation of cytoplasmic and nuclear extract}

Nuclear and cytoplasmic extracts were prepared as described previously (Schoonbroodt et al., 1997). Briefly, after cell activation for the times indicated cells were washed with ice-cold PBS and resuspended in $60 \mathrm{ml}$ of buffer A (10 mM Hepes/KOH, $2 \mathrm{mM}$ $\mathrm{MgCl}_{2}, 0.1 \mathrm{mM}$ EDTA, $10 \mathrm{mM} \mathrm{KCl}, 1 \mathrm{mM}$ DTT, and 0.5 mM PMSF, pH 7.9). The cells were allowed to swell on ice for $15 \mathrm{~min}$, lysed gently with $2.5 \mathrm{ml}$ of $10 \%$ Nonide P-40, and centrifuged at $1200 \times \mathrm{g}$ for $10 \mathrm{~min}$ at $4{ }^{\circ} \mathrm{C}$. The supernatant was collected and used as the cytoplasmic extracts. The nuclei pellet was resuspended in $40 \mathrm{ml}$ of buffer B $(50 \mathrm{mM}$ HEPES/KOH, $50 \mathrm{mM} \mathrm{KCl,} 300 \mathrm{mM} \mathrm{NaCl}, 0.1 \mathrm{mM}$ EDTA, $10 \%$ glycerol, $1 \mathrm{mM}$ DTT, and $0.5 \mathrm{mM}$ 
PMSF, pH 7.9), left on ice for $20 \mathrm{~min}$, and inverted. The nuclear debris was then spun down at $1200 \times \mathrm{g}$ for $15 \mathrm{~min}$. The supernatant (nuclear extract) was collected, frozen in liquid nitrogen and stored at $70{ }^{\circ} \mathrm{C}$ until conducting the analysis.

\section{Western blot analysis}

For analysis of the levels of NF-кB, p-IкB- $\alpha$, and IкB- $\alpha$, stimulated cells were rinsed twice with icecold PBS and were then lysed in ice-cold lysis buffer (1\% Triton, $1 \%$ Nonidet P- $40,0.1 \%$ SDS, $1 \%$ deoxycholate in PBS). Cell lysates were centrifuged at $15,000 \times \mathrm{g}$ for $5 \mathrm{~min}$ at $4{ }^{\circ} \mathrm{C}$; the supernatant was then mixed with an equal volume of $2 \times$ SDS sample buffer, boiled for $5 \mathrm{~min}$, and then separated through 10\% SDS-PAGE gels. After electrophoresis, the protein was transferred to nylon membranes by electrophoretic transfer. The membranes were blocked in 5\% skim milk for $2 \mathrm{~h}$, rinsed, and incubated overnight at $4{ }^{\circ} \mathrm{C}$ with primary antibodies in PBS/0.5\% Tween 20. Excess primary antibody was then removed by washing the membranes four times in PBS/0.5\% Tween 20, and the membranes were incubated for $1 \mathrm{~h}$ with HRP-conjugated secondary antibodies (against mouse, or rabbit). After three washes in PBS/0.5\% Tween 20, the protein bands were visualized by an enhanced chemiluminesence assay (Amersham Pharmacia Biotech, NJ, USA) following the manufacturer's instructions.

\section{HPLC analysis}

The Alliance 2695 HPLC system consisted of a pump (Waters Assoc., USA: 501 HPLC pump), a 2996 PDA detector (Water Assoc., USA: 2996 PDA detector), an autosampler (Water Assoc., USA: 746 computing integrator). A YMC-Pack ODS-AQ 303 colum $(4.6 \mathrm{~mm} \times 250 \mathrm{~nm}, 5 \mathrm{~m})$ was used. Buffer ( $25 \mathrm{mM} / \mathrm{L}$ phosphoric acid, $\mathrm{pH}$ 2.25): Acetonitrile (80:20) was used as the mobile phase. Detection of the peaks was made at $210 \mathrm{~nm}$ and the sensitivity was set of 1.0 AUFs. The injection volume was 20 $\mathrm{ml}$ and flow rate was $1.0 \mathrm{ml} / \mathrm{min}$. Standard solution was prepared by dissolving in distilled water ( 10 $\mathrm{mg} / 100 \mathrm{ml})$. The solution was filtered through 0.45 $\mathrm{ml}$ membrane filter and applied to HPLC.

\section{Statistical analysis}

The results were expressed as mean \pm S.E.M. for a number of experiments. Statistical significance was compared between each treated group and control by analysis of variance (ANOVA), with a Tukey post hoc test. For all tests, $P$ value less than 0.05 was considered significant.

\section{RESULTS}

\section{Effect of SSE on compound 48/80-induced systemic anaphylaxis}

To assess the contribution of SSE in anaphylactic reactions, we first used the in vivo model of systemic anaphylaxis. As a non-immunologic stimulator, compound $48 / 80(8 \mathrm{mg} / \mathrm{kg})$ was used. After the injection of compound $48 / 80$, the mice were monitored for $23 \mathrm{~min}$, after which the mortality rate was determined. The period for observation of mortality was based on the control mice that had died in $23 \mathrm{~min}$ by compound $48 / 80$. As shown in Table 2, an oral administration of saline as a control induced a fatal reaction in 100\% of each group. When the SSE was orally administered at concentrations of $0.01-1 \mathrm{~g} / \mathrm{kg} 1 \mathrm{~h}$

Table 2. Effect of SSE on compound 48/80-induced systemic anaphylactic reaction in mice

\begin{tabular}{ccc}
\hline $\begin{array}{c}\text { SSE dose } \\
(\mathrm{g} / \mathrm{kg})^{\mathrm{a}}\end{array}$ & $\begin{array}{c}\text { Compound 48/80 } \\
(8 \mathrm{mg} / \mathrm{kg})^{\mathrm{b}}\end{array}$ & $\begin{array}{c}\text { Mortality } \\
(\%)^{\mathrm{c}}\end{array}$ \\
\hline None (saline) & + & 100.0 \\
0.01 & + & 50.0 \\
0.1 & + & 33.3 \\
1 & + & 16.7 \\
\hline
\end{tabular}

${ }^{\text {a The groups of mice }(n=5) \text { were orally pretreated }}$ with $200 \mu \mathrm{l}$ of saline or SSE was given at various doses $1 \mathrm{~h}$ before the compound 48/80 injection. ${ }^{\mathrm{b}}$ The compound $48 / 80$ solution was intraperitoneally given to the groups of mice. ${ }^{\mathrm{C}}$ Mortality (\%) is presented as the 'Number of dead mice $\times 100 /$ Total number of experimental mice'. 
Table 3. Effects of SSE on compound 48/80-induced ear swelling response, and on PCA in mice

\begin{tabular}{ccccc}
\hline \multirow{2}{*}{$\begin{array}{c}\text { Dose of SSE } \\
(\mathrm{g} / \mathrm{kg})\end{array}$} & \multicolumn{2}{c}{ Ear swelling response $^{\mathrm{a}}$} & \multicolumn{2}{c}{ PCA $^{\mathrm{b}}$} \\
\cline { 2 - 5 } & Thickness of ear $(\mathrm{mm})$ & Inhibition $(\%)$ & Amount of dye $(\mu \mathrm{g} / \mathrm{site})$ & Inhibition (\%) \\
\hline None & $0.293 \pm 0.002$ & & $2.811 \pm 0.275$ & \\
0.01 & $0.247 \pm 0.010^{*}$ & 15.60 & $2.453 \pm 0.538$ & 12.70 \\
0.1 & $0.199 \pm 0.007^{*}$ & 32.12 & $2.013 \pm 0.242^{*}$ & 28.40 \\
1 & $0.135 \pm 0.009^{*}$ & 53.76 & $1.880 \pm 0.354^{*}$ & 32.74 \\
\hline
\end{tabular}

${ }^{a} 20 \mathrm{ml}$ of compound $48 / 80(100 \mathrm{mg} / \mathrm{site})$ were applied intradermally. The mice were orally administered with the various concentrations $(0.01,0.1$ and $1.0 \mathrm{~g} / \mathrm{kg})$ of SSE for $1 \mathrm{~h}$ prior to the compound $48 / 80$ application. Each datum represents the means \pm S.E.M. of three independent experiments. ${ }^{*} P<0.05$, significantly different from the saline value. 'Saline or SSE was applied orally $1 \mathrm{~h}$ prior to the challenge with antigen. Each amount of dye represents the means \pm S.E.M. of three independent experiments. ${ }^{*} P<0.05$, significantly different from the saline value.

before compound $48 / 80$ injections, the mortality was reduced (Table 2).

\section{Effect of SSE on ear swelling response and PCA in mice}

To investigate the effect of SSE on allergy response in vivo, we performed the ear swelling and PCA in mice. We choose a concentration of $100 \mathrm{mg} /$ site for compound 48/80 induced optimal ear-swelling response in this experiment. As shown in Table 3a, when mice were pretreated with SSE for $1 \mathrm{~h}$, the ear swelling response derived from compound 48/ 80 was reduced in dose-dependent manner $(P<$ $0.05)$. Inhibition rate of SSE $(0.01-1 \mathrm{~g} / \mathrm{kg})$ on earswelling response was about $15.60 \%(P<0.05), 32.12 \%$ $(P<0.05)$, and $53.76 \%(P<0.05)$, respectively.

PCA is one of the most important in vivo models of anaphylaxis in local allergic reactions (Wershil et al., 1987). When SSE was orally administered to the mouse, the PCA reaction was inhibited in a dosedependent manner (Table $3 b$ ). Inhibition rate of SSE $(0.01-1 \mathrm{~g} / \mathrm{kg})$ on PCA reaction was about $12.70 \%(P>0.05), 28.40 \%(P<0.05)$, and $32.74 \%(P$ $<0.05)$, respectively.

\section{Effect of SSE on histamine release and degranulation from RPMCs}

Histamine has been widely used as a marker of mast cell degranulation in vitro, and remains the best-characterized and most potent mediator implicated in the acute phase of immediate

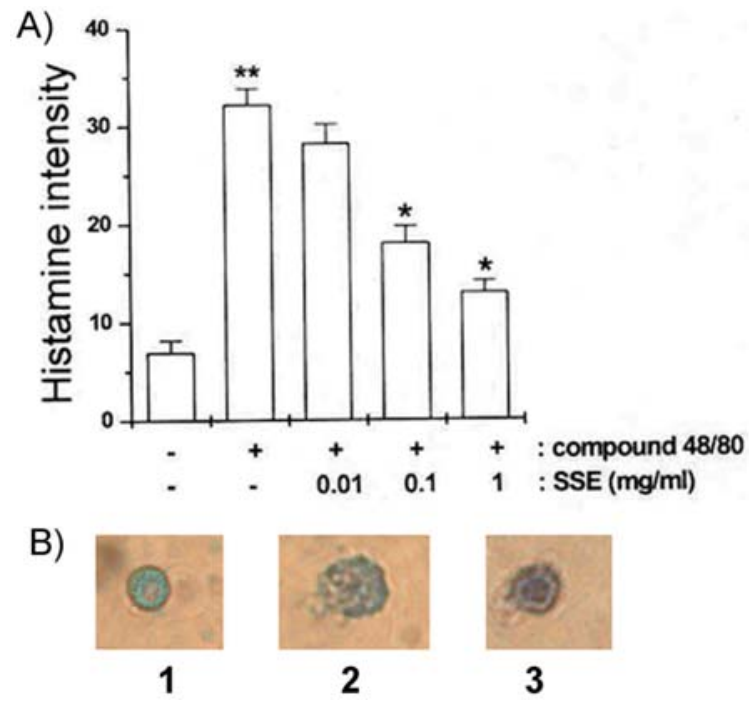

Fig. 1. Effect of SSE on histamine release and degranulation from RPMCs. A) RPMCs $\left(2 \times 10^{5}\right.$ cells $)$ were preincubated with various concentrations of SSE at $37{ }^{\circ} \mathrm{C}$ for $10 \mathrm{~min}$ and then incubation with compound 48/80. The histamine content was measured by the spectrofluorometer as described under material and methods. B) The photographs of alcian blue-NFR stained mast cells. 1) blank; 2) Compound 48/80 - stimulated RPMCs; 3) SSE (1 mg/ $\mathrm{ml})+$ Compound 48/80 - stimulated RPMCs. Magnifications were $\times 400$. All data represent the mean \pm S.E.M. of four independent experiments. ${ }^{*} P<$ 0.05 , significantly different from the compound 48 / 80 -stimulated cells. ${ }^{* *} P<0.01$, significantly different from the unstimulated cells.

hypersensitivity (Petersen et al., 1996; Moon et al., 2003). The inhibitory effect of SSE on compound 48/80-induced histamine release from RPMCs is shown in Fig. 1A. SSE dose dependently inhibited 
compound 48/80-induced histamine release at concentrations of $0.01-1 \mathrm{mg} / \mathrm{ml}$. In particular, SSE significantly inhibited the compound 48/80-induced histamine release at concentrations of $0.1-1 \mathrm{mg} / \mathrm{ml}$. Inhibition rate of the histamine release at the doses of $0.1-1 \mathrm{mg} / \mathrm{ml}$ was about $43.75 \%(P<0.05)$ and $59.68 \%(P<0.05)$, respectively.

The photographs of alcian blue-NFR stainedRPMCs are shown in Fig. 1B. Compound 48/80stimulated RPMC in the absence SSE was extensively degranulated compared with SSE-treated cell, which is correlated with an inhibition of histamine release. The results indicate that SSE inhibits the compound 48/80-induced degranulation from mast cells.

Effect of SSE on cytokine production and expression in PMA plus A23187-stimulated HMC-1

To assess the effect of SSE in PMA plusA23187induced TNF- $\alpha$, IL- 6 , and IL- 8 production, the cells were pretreated with various concentrations of SSE $(0.01-1 \mathrm{mg} / \mathrm{ml})$ for $30 \mathrm{~min}$, and then treated with PMA plus A23187 for $8 \mathrm{~h}$. Our results showed that PMA plus A23187 enhanced the secretion of TNF$\alpha$, IL-6, and IL-8, and these increase was inhibited by SSE in a dose-dependent manner (Fig. 2A). The maximal inhibition rate of TNF- $\alpha$, IL-6, and IL-8 production by SSE $(1 \mathrm{mg} / \mathrm{ml})$ was about $47.1 \%(P$ $<0.01)$, 63.1\% $(P<0.05)$ and $41.1 \%(P<0.05)$, respectively.

To investigate effect of SSE on TNF- $\alpha$, IL-6, and IL-8 expression, we performed RT-PCR. The cells were pretreated with various concentrations of SSE for $30 \mathrm{~min}$, and then treated with PMA plusA23187 for $4 \mathrm{~h}$. We showed that PMA plus A23187 induced the TNF- $\alpha$, IL- 6 , and IL-8 expression, but pretreatment of SSE decreased the TNF- $\alpha$, IL- 6 , and IL- 8 mRNA level in a dose-dependent manner (Fig. 2B). Cell cytotoxicity by SSE was not observed (data not shown).

Effect of SSE on COX-2 expression in PMA plus A23187-stimulated HMC-1

To determine the effect of SSE on COX-2 expression

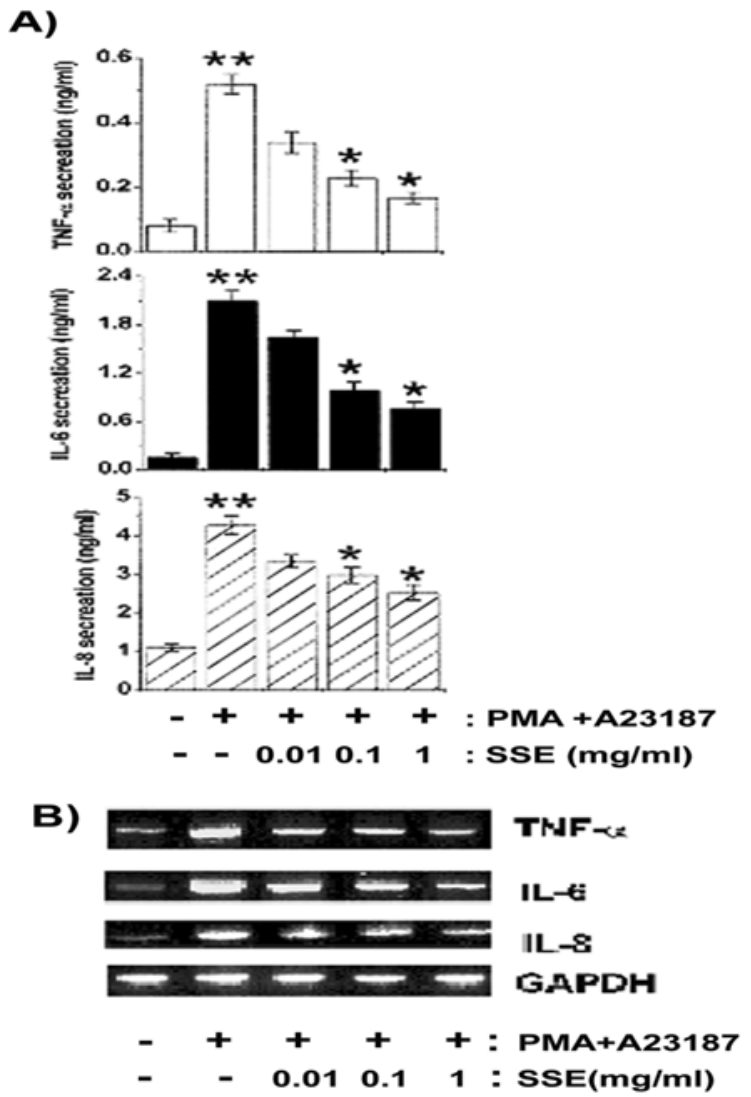

Fig. 2. Effect of SSE on cytokines production and expression in PMA plus A23187-stimulated HMC-1 cells. A) $3 \times 10^{5}$ HMC- 1 cells were treated with SSE $(0.01-1 \mathrm{mg} / \mathrm{ml})$ for $30 \mathrm{~min}$, and then stimulated with PMA (50 nM) plus A23187 (1 mg/ml) for 8 h. Cytokines concentration was measured in cell supernatants using the ELISA method. B) $5 \times 10^{6} \mathrm{HMC}-1$ cells were treated with SSE $(0.01-1 \mathrm{mg} / \mathrm{ml})$ for $30 \mathrm{~min}$, and then stimulated with PMA $(50 \mathrm{nM})$ plus A23187 (1 mg/ $\mathrm{ml})$ for $4 \mathrm{~h}$. The total RNA was assayed by RT-PCR analysis. 1) blank; 2) PMA + A23187;3) PMA + A23187 + $0.01 \mathrm{mg} / \mathrm{ml} \mathrm{SSE}$; 4) PMA + A23187 + $0.1 \mathrm{mg} / \mathrm{ml} \mathrm{SSE}$; 5) PMA + A23187 + $1 \mathrm{mg} / \mathrm{ml} \mathrm{SSE}$. All data represent the mean \pm S.E.M. of four independent experiments. ${ }^{*} P<0.05$, significantly different from the PMA plus A23187-stimulated cells. ${ }^{*} P<0.01$, significantly different from the unstimulated cells.

induced by PMA plus A23187, RT-PCR was performed. As shown in Fig. 3A, COX-2 mRNA expression was increased by PMA plus and A23187 for $12 \mathrm{~h}$, and pretreatment of SSE (0.01 - 1 $\mathrm{mg} / \mathrm{ml}$ ) inhibited the COX-2 mRNA level in dose 
A)

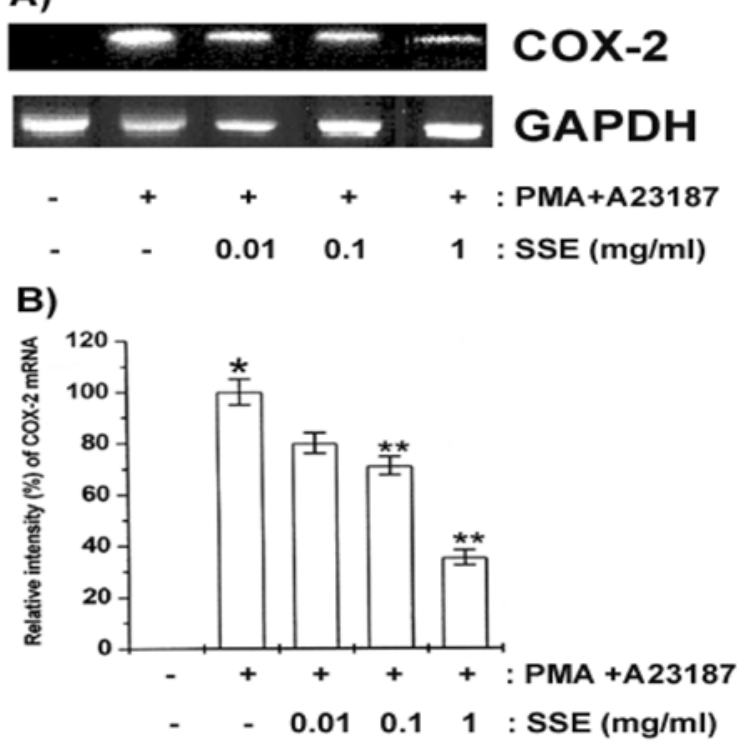

Fig. 3. Effect of SSE on COX-2 expression in PMA plus A23187-stimulated HMC-1 cells. A) Cells $\left(5 \times 10^{6}\right.$ cells $/ \mathrm{ml})$ were pretreated with SSE $(0.01-1 \mathrm{mg} / \mathrm{ml})$ for $30 \mathrm{~min}$, and then stimulated with PMA $(50 \mathrm{nM})$ plus A23187 $(1 \mathrm{mg} / \mathrm{ml})$ for $12 \mathrm{~h}$. Then, COX-2 mRNA level was assayed by RT-PCR. B) The relative mRNA amounts were estimated by an image analyzer. 1) blank; 2) PMA + A23187; 3) PMA + A23187 + $0.01 \mathrm{mg}$ / ml SSE; 4) PMA + A23187 + 0.1 mg/ml SSE; 5) PMA + $\mathrm{A} 23187+1 \mathrm{mg} / \mathrm{mlSSE}$. Results show a representative of four experiments, and the mean \pm S.E.M. of the band intensities corresponding to the levels of COX-2. ${ }^{*} P<$ 0.05 , significantly different from the unstimulated cells. ${ }^{* *} P<0.01$, significantly different from the PMA plus A23187-stimulated cells.

dependent manner. The relative mRNA amounts were estimated by using image analyzer (VILBER LOURMAT FC-26WL, France) (Fig. 3B).

Effect of SSE on NF-kB activation and IkB- $\alpha$ phosphorylation and degradation in PMA plus A23187-Stimulated HMC-1

Since NF- $\mathrm{\kappa B}$ activation requires nuclear translocation of RelA/p65 subunit of NF- $\mathrm{kB}$, we examined the effect of SSE on the cytosolic and nuclear pool of RelA/p65 protein by Western blot analysis in HMC-1. As shown in Fig. 4A, we showed that PMA plus A23187 treatment considerably increased the nuclear RelA/p65 protein level and decreased the

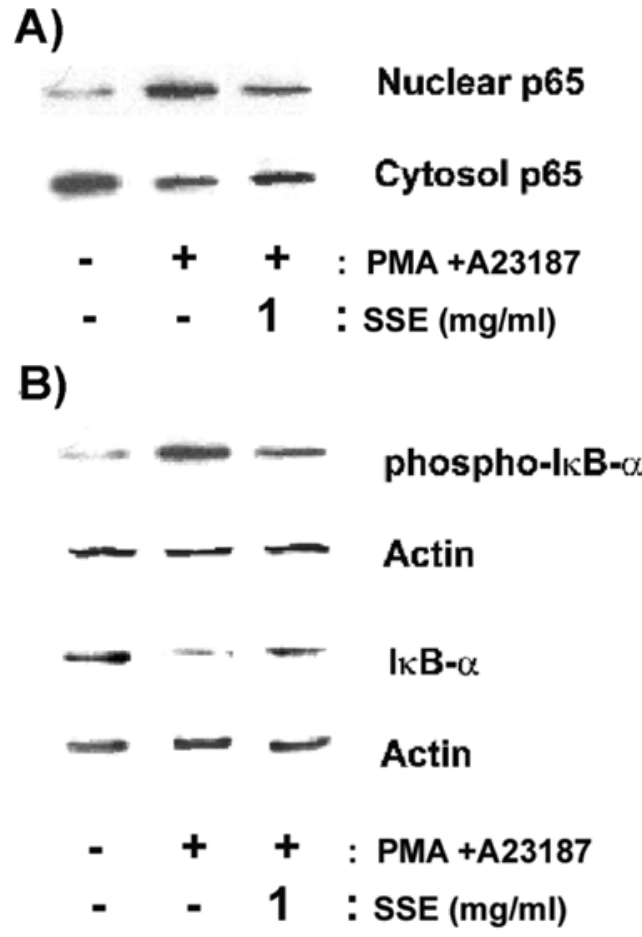

Fig. 4. Effect of SSE on NF-kB activation and IkB-a degradation/phosphorylation in PMA plus A23187stimulated HMC-1 cells. A) $6 \times 10^{6} \mathrm{HMC}-1$ cells were preincubated for $30 \mathrm{~min}$ with SSE $(0.01-1 \mathrm{mg} / \mathrm{ml})$ and then treated with PMA (50 nM) plus A23187 (1 $\mathrm{mg} / \mathrm{ml}$ ) for $2 \mathrm{~h}$. The cytosolic and nuclear extracts were determined for RelA/p65 by Western blot anlaysis. B) The cytosolic extracts were determined for IкB- $\alpha$, phospho-IкB- $\alpha$ by Western blot anlaysis. 1) blank; 2) PMA + A23187; 3) PMA + A23187 + SSE (1 $\mathrm{mg} / \mathrm{ml}$ ).

cytosolic RelA/p65, which is an indication of the nuclear translocation of RelA/p65. Pretreatment of SSE $(1 \mathrm{mg} / \mathrm{ml})$ inhibited the PMA plus A23187 stimulated increase and decrease of the nuclear and cytosolic RelA/p65 levels, respectively. These results suggested that SSE blocks the nuclear translocation of the RelA/p65 from cytoplasm.

Most agents that activate NF- $\mathrm{kB}$ mediate their effects through suppressing I $\mathrm{B}-\alpha$ phosphorylation and degradation (Yamamoto et al., 1999). As shown in Fig. 4B, PMA plus A23187 treatment effectively caused an induction of IкB- $\alpha$ phosphorylation, and degradation in HMC-1. We showed that SSE (1 $\mathrm{mg} / \mathrm{ml}$ ) significantly inhibited PMA plus A23187- 


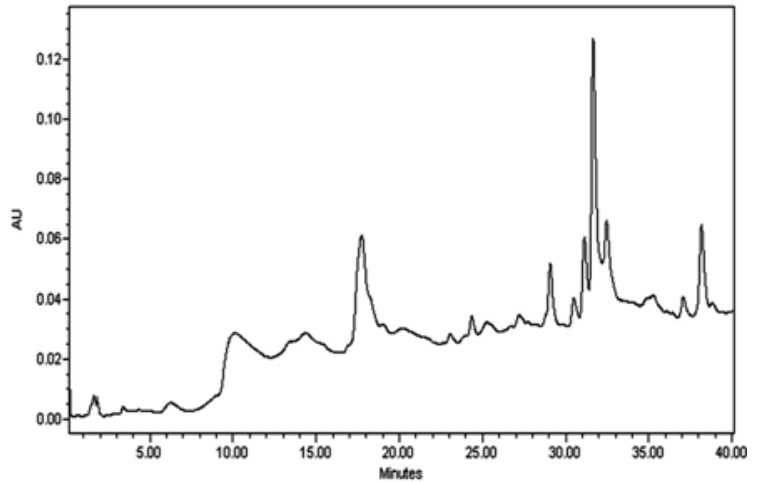

Fig. 5. HPLC Chromatogram of the SSE. The solution of SSE was prepared by dissolving in distilled water $(10 \mathrm{mg} / 100 \mathrm{ml})$. The injection volume was $20 \mathrm{ml}$ and the detection was made at $254 \mathrm{~nm}$.

induced IкB- $\alpha$ phosphorylation and degradation.

\section{Characterization of the principal components of SSE}

The components of SSE were analyzed by HPLC. The SSE can be efficiently resolved by the applied method and were identified according to the retention times of the respective standards. Chromatogram of the SSE is shown in Fig. 5. Peaks of the principal components have not yet been identified in this study.

\section{DISCUSSION}

SSE is an oriental medication water-extracted from the herb medicines, which consists of 12 different herbs. Other studies reported that each medicine herb has different effects. For example, Ginsenosides isolated from the root of Ginseng Radix had the inhibitory activity on beta-hexosaminidase release from RBL-2H3 cells and on the PCA reaction (Choo et al., 2003), saponins of ginseng root has inhibitory effects on IL-1 $\beta$ and IL-6 gene expression in chronic inflammation model of aged rats $(\mathrm{Yu}$ and $\mathrm{Li}, 2000$ ), Platycodin $\mathrm{D}$, isolated from the root of Platycodi Radix has anti-inflammatory effect through inhibition of $\mathrm{PGE}_{2}$ production in rat peritoneal macrophages (Kim et al., 2001), and 6-
Gingerol, one of the major components of fresh Zingiberis Rhizoma, protects HL-60 cells from oxidative stress (Wang et al., 2003). SSE composed on the basis of the theory of Korean medicine to maximize its efficacy. However, the mechanism involved in anti-allergy and anti-inflammatory effect of SSE has not been examined. In this study, our findings show that SSE inhibited the compound 48/80-induced and IgE+Ag-induced allergic reactions in vivo and inhibited the TNF- $\alpha$, IL-8, and COX-2, expression in PMA plus A23187-simulated HMC-1 cells. In addition, SSE inhibited NF-кB activation through suppression of IKB- $\alpha$ phosphorylation and degradation.

Mast cells are widely distributed throughout the body in both connective tissue and at mucosal surfaces (Metcalfe et al., 1997). The role of mast cells as effecter cells of IgE-dependent immediate-type hypersensitivity reactions and anaphylaxis is well understood (Hamelmann et al., 1993; Galli, 2000). It was reported that compound $48 / 80$ increased the permeability of the lipid bilayer membrane by causing a perturbation of the membrane indicates, which may be an essential trigger for the release of mediators from mast cells (Tasak et al., 1986). In present study, we showed that SSE inhibited the systemic anaphylaxis and ear swelling caused by compound 48/80 in mice. Also, SSE inhibited histamine release and degranulation from RPMCs. So, it is possible to hypothesize that SSE might act on the lipid bilayer membrane affecting the prevention of the perturbation being induced by compound $48 / 80$. PCA is a very effective way to test skin allergic reactions, which has been successfully applied in murine model with oriental medicine (Kim et al., 2000). In this study, we utilized PCA for testing protection effect from IgE-mediated local allergic reaction. We showed that SSE inhibited PCA response in dose dependent manner. This result suggested that SSE inhibits the initial phase of immediate type allergic reactions, probably through interference with the degranulation.

As mast cells contain potent mediators including 
PGs and multifunctional cytokines, they contribute to the pathogenesis of chronic inflammatory disease. Therefore, mast cell activation significantly contributes to the initiation of exacerbation of inflammation. Inflammatory cytokines (TNF- $\alpha$ and IL-6) play roles in mediating the progression of many inflammatory diseases. TNF- $\alpha$ from mast cells can orchestrate the migration of neutrophils and T-lymphocytes into tissues, and promote chronicity in inflammatory lesions (Walsh et al., 1995). IL-8 from mast cells act on surrounding cells such as neutrophils, T-lymphocytes, and eosinophils, and activation of inflammatory effector cells (Mukaida, 2000). COX-2, one of the major mediators of the inflammatory reaction is also strongly induced in activated monocytes/macrophages. Several recent studies demonstrated that $\mathrm{PGD}_{2}$, which is the COX-2 metabolite released from activated mast cells, is also essential for the pathogenesis of eosinophilic airway inflammation (Bochenek et al., 2004). Previously, it has been reported that COX-2 inhibitors abolished $\mathrm{PGD}_{2}$ synthesis and attenuated eosinophil accumulation in the airways inflammation (O'Sullivan et al., 1998; Oguma et al., 2002). In this study, we observed that SSE inhibited TNF- $\alpha$, IL-6, IL-8, and COX-2 expression in HMC-1. These results indicated that SSE has potential effect on anti-inflammatory response through the regulation of inflammatory genes in mast cells, which might explain its beneficial effect in the treatment of mast cell-mediated inflammatory diseases.

NF- $\kappa \mathrm{B}$ is required for transcriptions proinflammatory molecules, including COX-2 and cytokines such as TNF- $\alpha$, IL- 6 and IL-8. Since these pro-inflammatory molecules are regulated at the transcription level, NF-kB is a critical intracellular mediator of the inflammatory cascade (Ghosh et al., 1998). Therefore, we postulated that SSE mediates its effects at least partly through suppression of $\mathrm{NF}-\kappa \mathrm{B}$ activation. In an inactive state, NF- $\mathrm{\kappa B}$ is present in the cytoplasm as a heterodimer consisting of p50/ p65, and IкB- $\alpha$ subunits. In response to an activation signal, theIkB- $\alpha$ subunit is phosphorylated, ubiquitinated, and degraded through the proteosomal pathway, thus exposing the nuclear localization signals on the p50-p65 heterodimer. The p65 is then phosphorylated, leading to nuclear translocation and binding to a specific sequence in DNA, which in turn results in gene transcription. Inhibitors of NF$\kappa \mathrm{B}$ activation mediate their effects through suppressing IкB- $\alpha$ phosphorylation and degradation (Yamamoto et al., 1999). For example, when cells were stimulated with LPS in the presence of sodium calculate or aspirin, the LPS-induced proteolysis of IкB- $\alpha$ was abolished, which suggests that the observed NF- $\mathrm{KB}$ inhibition was mediated through inhibition of the phosphorylation and /or degradation of IкB- $\alpha$. Previously, we reported that aucubin inhibited the NF-kB activation via phosphorylation and degradation of IKB- $\alpha$ (Jeong et al., 2002). In this study, we showed that SSE suppressed NF-kB translocation to the nucleus induced by PMA plus A23187. Also this suppression was mediated through inhibition of IkB- $\alpha$ phosphorylation and degradation. Therefore, our results suggest that the anti-inflammatory effect of SSE is similar to the mechanism of aucubin. So, it is possible to hypothesize that SSE might act as a potent NF- $\mathrm{KB}$ inhibitor on the mast cell activation induced by PMA plus A23187.

In conclusion, we have shown that SSE can regulate allergy response in vivo, and affect the expression of inflammatory genes through regulation of the NF- $\kappa \mathrm{B} / \mathrm{I} \mathrm{KB}-\alpha$ pathway. These results provided new insight into the pharmacological actions of SSE as a potential molecule for therapy of inflammatory allergic diseases.

\section{ACKNOWLEDGEMENTS}

This research was supported by Wonkwang University in 2009.

\section{REFERENCES}

Artuc M, Hermes B, Steckelings UM, Grutzkau A, Henz BM. (1999) Mast cells and their mediators in 
cutaneous wound healing-active participants or innocent bystanders Exp. Dermatol. 8, 1-16.

Barnes PJ, Karin M. (1997) Nuclear factor-kappaB: a pivotal transcription factor in chronic inflammatory diseases. New Engl. J. Med. 336, 1066-1071.

Beutler B. (1995) TNF, immunity and inflammatory disease: lessons of the past decade. J. Invest. Med. 43, 227-235.

Bochenek G, Nizankowska E, Gielicz A, Swierczynska M, Szczeklik A. (2004) Plasma 9alpha, 11beta-PGF2, a PGD2 metabolite, as a sensitive marker of mast cell activation by allergen in bronchial asthma. Thorax. 59, 459-464.

Choo MK, Park EK, Han MJ, Kim DH. (2003) Antiallergic activity of ginseng and its ginsenosides. Planta Med. 69, 518-522.

Galli SJ. (2000) Allergy. Curr. Biol. 10, 93-95.

Ghosh S, May MJ, Kopp EB. (1998) NF-кB and Rel proteins: evolutionarily conserved mediators of immune responses. Annu. Rev. Immunol. 16, 225-260.

Gordon JR, Burd PR, Galli SJ. (1990) Mast cells as a source of multifunctional cytokines. Immunol. Today 11, 458-464.

Hamelmann E, Tadeda K, Oshiba A, Gelfand EW. (1999) Role of $\operatorname{IgE}$ in the development of allergic airway inflammation and airway hyperresponsiveness. Allergy 54, 297-305.

Jeong HJ, Koo HN, Na HJ, Kim MS, Hong SH, Eom JW, Kim KS, Shin TY, Kim HM. (2002) Inhibition of TNF-alpha and IL-6 production by Aucubin through blockade of NF-kappaB activation RBL-2H3 mast cells. Cytokine 18, 252-259.

Jippo-Kanemoto T, Kasugai T, Yamatodani A, Ushio H, Mochizuki T, Tohya K, Kimura M, Nishimura M, Kitamura Y. (1993) Supernormal histamine release and normal cytotoxic activity of beige (ChediakHigashi syndrome) rat mast cells with giant granules. Int. Arch. Allergy Immunol. 100, 99-106.

Jung YJ, Isaacs JS, Lee S, Trepel J, Neckers L. (2003) IL1beta-mediated up-regulation of HIF-1alpha via an NFkappaB/COX-2 pathway identifies HIF-1 as a critical link between inflammation and oncogenesis. FASEB J. 17, 2115-2117.

Kawata R, Reddy ST, Wolner B, Herschman HR. (1995) Prostaglandin synthase 1 and prostaglandin synthase 2 both participate in activation-induced prostaglandin D2 production in mast cells. J. Immunol. 155, 818-
825.

Kim MS, Lim WK, Cha JG, An NH, Yoo SJ, Park JH, Kim HM, Lee YM. (2001) The activation of PI 3-K and PKC zeta in PMA-induceddifferentiation of HL-60 cells. Cancer Lett. 171, 79-85.

Kim SH, Choi YK, Jeong HJ, Kang HU, Moon G, Shin TY, Kim HM. (2000) Suppression of immunoglobulin E-mediated anaphylactic reaction by Alpini oxyphylla in rats. Immunopharmacol. Immunotoxicol. 22, 267-277.

Kim YP, Lee EB, Kim SY, Li D, Ban HS, Lim SS, Shin $\mathrm{KH}$, Ohuchi K. (2001) Inhibition of prostaglandin E2 production by platycodin $\mathrm{D}$ isolated from the root of Platycodon grandiflorum. Planta Med. 67, 362-364.

Kruger-Krasagakes S, Czarnetzki BM. (1995) Cytokine secretion by human mast cells. Exp. Dermatol. 4, 250-254.

Meade EA, Smith WL, DeWitt DL. (1993) Antioxidant activity and inhibitory effects of hydralazine on inducible NOS/COX-2 gene and protein expression in rat peritoneal macrophages. J. Bio. Chem. 268, 6610-6614.

Medzhitov R, Janeway CA Jr. (1997) Innate immunity: the virtues of a nonclonal system of recognition. Cell 91, 295-298.

Metcalfe DD, Baram D, Mekori YA. (1997) Mast cells. Physiol. Rev. 77, 1033-1079.

Moon PD, Na HJ, Kim HM. (2003) Action of enzyme food, Green Life Enzyme of systemic and local anaphylaxis. Orient. Pharm. Exp. Med. 3, 46-50.

Mukaida N. (2000) Inerleukin-8: and expanding universe beyond neutrophil chemotaxis and activation. Int. J. Hematol. 72, 391-398.

Na HJ, Jeong HJ, Bae H, Kim YB, Park ST, Yun YG, Kim HM. (2002) Tongkyutang inhibits mast celldependent allergic reactions and inflammatory cytokines secretion. Clin. Chim. Acta 7, 35-41.

O'Sullivan S, Dahlen SE, Larsson K, Larsson BM, Malmberg P, Kumlin M, Palmberg L. (1998) Exposure of healthy volunteers to swine house dust increases formation of leukotrienes, prostaglandin D2, and bronchial responsiveness to methacholine. Thorax 53, 1041-1046.

Oguma T, Asano K, Shiomi T, Fukunaga K, Suzuki Y, Nakamura M, Matsubara H, Sheldon HK, Haley KJ, Lilly CM, Drazen JM, Yamaguchi K. (2002) Cyclooxygenase-2 expression during allergic 
inflammation in guinea-pig lungs. Am. J. Respir. Crit. Care Med. 165, 382-386.

Petersen LJ, Mosbech H, Skov PS. (1996) Allergeninduced histamine release in intact human skin in vivo assessed by skin microdialysis technique: characterization of factors influencing histamine releasability. J. Allergy Clin. Immunol. 97, 672-679.

Schaecher K, Goust JM, Banik NL. (2004) The effects of calpain inhibition on I $\mathrm{B}$ alpha degradation after activation of PBMCs: identification of the calpain cleavage sites. Neurochem. Res. 29, 1443-1451.

Schoonbroodt S, Legrand-Poels S, Best-Belpomme M, Piette J. (1997) Activation of the NF-кB transcription factor in a T-lymphocytic cell line by hypochlorous acid. Biochem. J. 321, 777-775.

Shore PA, Burkhalter A, Cohn VH. (1959) A method for fluorometric assay of histamine in tissues. J. Pharmacol. Exp. Ther. 127, 182-186.

Tasaka K, Mio M, Okamoto M. (1986) Intracellular calcium release induced by histamine releasers and its inhibition by some antiallergic drugs. Ann. Allergy 56, 464-469.

Walsh LJ, Davis MF, Xu LJ, Savage NW. (1995)
Relationship between mast cell degranulation, release of TNF, and inflammation in the oral cavity. J. Oral Pathol. Med. 26, 266-272.

Wang CC, Chen LG, Lee LT, Yang LL. (2003) Effects of 6-gingerol, an antioxidant from ginger, on inducing apoptosis in human leukemic HL-60 cells. In Vivo 17, 641-645.

Wershil BK, Merkori YA, Murakami T, Galli SJ. (1987) 125I-fibrin deposition in IgE dependent immediate hypersensitivity reactions in mouse skin. Demonstration of the role of mast cells using genetically mast celldeficient mice locally reconstituted with cultured mast cells. J. Immunol. 139, 2605-2614.

Yamamoto Y, Yin MJ, Lin KM, Gaynor RB. (1999) Sulindac inhibits activation of the NF-kappaB pathway. J. Biochem. 274, 27307-27314.

Yu SC, Li XY. (2000) Effect of ginsenoside on IL-1 beta and IL-6 mRNA expression in hippocampal neurons in chronic inflammation model of aged rats. Acta Pharmacol. Sin. 21, 915-918.

Yurt RW, Leid RW, Austen KF. (1997) Native heparin from rat peritoneal mast cells. J.Biol. Chem. 252, 518521. 